\title{
Screening for adolescent alcohol and drug use in pediatrics: predictors and implications for practice and policy
}

\author{
Stacy Sterling ${ }^{1 *}$, Andrea Hessel ${ }^{1}$, Charles Wibbelsman² \\ From International Network on Brief Interventions for Alcohol and Other Drugs (INEBRIA) Meeting 2011 \\ Boston, MA, USA. 21-23 September 2011
}

We describe findings from a web survey of pediatric primary care providers (PCPs) and a pilot study of a screening, brief intervention, and referral to treatment (SBIRT) model of primary care-based adolescent behavioral health care. The survey $(\mathrm{N}=437)$ examined PCP attitudes and knowledge, patient characteristics, and environmental influences, (e.g., mental health parity and medical marijuana laws). We examined how PCP, panel, and organizational characteristics influence screening practices. The pilot examined whether SBIRT versus usual care increased problem identification and specialty treatment rates and the feasibility of SBIRT in pediatric patients. Respondents were less concerned about alcohol than other drug use, rated alcohol use as more difficult to discuss (19\% versus $15 \%$ ) and diagnose (56\% versus $70 \%$ ) than depression, and were more comfortable discussing sexual practices than alcohol (32\% versus $22 \%)$. They were more likely to screen boys than girls (male PCPs were even more likely: $23 \%$ versus $6 \%[\mathrm{p}<0.0001])$. Self-reported screening rates were far higher than electronic medical record (EMR)-documented rates for all substances. Experience, specialty, and recent AOD training (all $\mathrm{p}<0.05$ ) predicted self-reported rates; only patient age predicted actual rates. Organizational approaches (e.g., EMR tools and workflow) may matter more than PCP or patient characteristics in determining screening. Respondents reported that SBIRT was highly feasible and that it improved care; more (77) teens receiving SBIRT were referred for further assessment than those receiving usual care, and specialty treatment initiation increased from $8.73 \%$ to $12 \%$ ( $\mathrm{p}<0.0001)$. Organizational factors, lack of training, and discomfort with screening may impact adolescent screening and intervention.

Kaiser Permanente Northern California Division of Research, Oakland, CA, USA

Full list of author information is available at the end of the article
Integrated models of care for adolescent behavioral health care should be considered.

\section{Author details}

${ }^{1}$ Kaiser Permanente Northern California Division of Research, Oakland, CA, USA. ${ }^{2}$ Kaiser Permanente Northern California/San Francisco Medical Center, San Francisco, CA, USA.

Published: 9 October 2012

doi:10.1186/1940-0640-7-S1-A15

Cite this article as: Sterling et al: Screening for adolescent alcohol and drug use in pediatrics: predictors and implications for practice and policy. Addiction Science \& Clinical Practice 2012 7(Suppl 1):A15.

Submit your next manuscript to BioMed Central and take full advantage of:

- Convenient online submission

- Thorough peer review

- No space constraints or color figure charges

- Immediate publication on acceptance

- Inclusion in PubMed, CAS, Scopus and Google Scholar

- Research which is freely available for redistribution
C Biomed Central

ㄷ 2012 Sterling et al; licensee BioMed Central Ltd. This is an Open Access article distributed under the terms of the Creative Commons Attribution License (http://creativecommons.org/licenses/by/2.0), which permits unrestricted use, distribution, and reproduction in any medium, provided the original work is properly cited. 